\title{
THE CONCEPTUALISATION AND MEASUREMENT OF COMBAT READINESS FOR PEACE-SUPPORT OPERATIONS - AN EXPLORATORY STUDY
}

\author{
PIET C BESTER \\ KAREL J STANZ \\ Department of Human Resource Management \\ University of Johannesburg
}

\begin{abstract}
The aim of this study was to conceptualise combat readiness and to construct a normative measurement instrument for use within the context of peace-support operations. The Peace-Support Operations Questionnaire (PSOQ) was developed comprising of three types of items, namely an associated component, a disassociated component, and certain generic items applicable to both components. The sample comprised 461 soldiers of the South African National Defence Force. A second-order factor analysis on the 15 sub-scores of the first-order factor analysis yielded two factors. These factors were interpreted as Military Climate and Discipline. The two factors were subjected to an item analysis and yielded reliability coefficients of 0,987 and 0,791 . The implications of these findings are discussed.
\end{abstract}

Key words: Measurements combat readiness, peace-support opporations

The South African White Paper on Defence (South African Department of Defence, 1996) makes provision for the South African National Defence Force (SANDF) to become involved in peace-support operations. Two broadly defined types of support operations are identified in which the SANDF might become involved. The first type pertains to peacekeeping (nowadays known as peace-support operations) which entails military operations undertaken without resorting to force and by getting the consent of the major parties to a dispute in order to monitor and facilitate the implementation of a peace agreement. The second type encompasses peace enforcement which entails the application or threat of force, pursuant to international authorisation, in order to compel compliance with resolutions or sanctions designed to maintain or restore peace and order. The implication is that soldiers of the SANDF must at least be able to engage in armed conflict if necessary.

Taking into consideration that the Republic of South Africa (RSA) also has a responsibility for peace-support operations, soldiers must be ready for combat not only during wartime, but also in peacetime (South African Department of Defence, 1996). The importance of soldiers in the military is emphasised by General Sir Peter Hunt, Former Chief of the British General Staff, in the following statement: “...Man and his behaviour has always been the most important factor in war, science, systems and technology notwithstanding, and surely it must be in peacetime..." (cited in Richardson, 1978). Sarkesian, Williams and Bryant (1995), on the other hand, mention that in the new security era (the post-apartheid era in the case of the RSA) military forces increasingly participate in non-traditional operations that pose new challenges in the political, social and military dimensions. This has a direct effect on the soldiers themselves. This view is supported by Newman (1998) in which he asks the question whether peacekeepers could make war.

On the basis of the aforementioned, the RSA's growing role in peace-support operations, specifically in Africa, raises a major concern, namely how ready or how well prepared South African troops are to participate in such operations. Van Vuuren (2000, p 6) of the SANDF's Defence Inspectorate emphasises this concern in the following statement: “...The more accurately readiness is captured and quantified, the better the chance to allocate effort and resources to the right places...". This statement emphasises the necessity of measuring combat readiness within the SANDF, and consequently to have a thorough understanding of what constitutes combat readiness.

\section{HISTORICAL BACKGROUND}

Various authors (Ingraham \& Manning, 1981; Manning, 1991; Richardson, 1978) are of the opinion that Xenophon was the first military writer to give attention to soldier morale when he stated that it is not numbers and strength that bring victory to war, but the army that goes into battle "stronger in soul"; their enemies generally cannot withstand them. Maurice de Sac (cited in Manning, 1991) stated 20 centuries later that the human heart is the starting point in all matters pertaining to war. A century later this was echoed by Napoleon's dictum that the moral is to the physical as three is to one, and in the end the Spirit will always conquer the Sword (Manning, 1991; Richardson, 1978). Colonel Ardant du Picq concluded from a study of sustaining soldiers in combat, that four brave men who do not know each other well, will not dare to attack a lion; but four less brave men knowing each other well and who are sure of their reliability and the consequences of mutual aid will attack resolutely (Ingraham \& Manning, 1981; Shay, 2000). This statement is echoed by Kruys (2001) when he states that all things being equal, the force with the best trained small units will win, but even if all is not equal, the side with the best skilled soldiers and determined small units will usually defeat larger and sometimes even better equipped units.

According to Brown and Moskos (1976) du Picq's work introduced the notion of soldier morale and had, up to then, the widest influence over the development of military theory and speculation about combat behaviour. According to Kirkland, Bartone and Marlowe (1993) the US Army began in the early 1970s to investigate whether human dimensions and psychological readiness are important for combat performance. This led to the publication of Field Manual 100-5 (Department of the Army, 1983) which states that wars are fought and won by men, not by machines, and that the human dimension of war will be decisive in the campaigns and battles of the future. Bartone and Kirkland (1991) report that trends toward increased violence and isolation on the battlefield have led military planners around the world to place increased emphasis on the psychological and human dimensions of force readiness.

Significant research on morale has been conducted by the Israeli Defence Force. The first study was done by Guttmann (cited in Gal, 1986) in 1949. He assessed soldiers' satisfaction with "arrangements" in their bases and their "mood". According to Gal (1986) Guttman's term "mood" is most probably a substitute term for morale. Gal (1986) analysed data from a morale survey 
administered during 1981 in the Golan Heights. During the late nineties Shamir, Brainin, Zakay and Popper (2000) did research on perceived combat readiness.

Within the South African context de Vries (1993) indicates that faith, good morale and leadership, motivation, organisational and command cohesion, group norms and culture are important for success in battle. Van Vuuren (2000) of the SANDF's Defence Inspectorate supports de Vries's opinion when he emphasises the importance of measuring combat readiness. The report stated that the measurement of combat readiness would be part of a cycle of measurement within the Department of Defence (DOD). After analysing various battles within the RSA history, de Vries (1993) concluded that the key to success on the battlefield is not only vested in the physical aspect (meaning numerical superiority, armaments and firepower), but equally in the psychological component. This view is supported by Lord Moran's remarks: “...It has always been a military axiom, that a man's will to fight is the ultimate arbiter of battles and that this is governed by the thoughts however elementary which pass through his head. It is not the number of soldiers, but their will to win which decides battles..." (cited in Baynes, 1967, p.92).

It seems appropriate to conclude this brief overview with the observation of Manning (1991) that one constant in the ever-changing nature of warfare over centuries has been the recognition that success on the battlefield involves more than the appropriate disposition of men and weapons. The concept of combat readiness within the South African context will be defined next, with specific reference to peace-support operations.

\section{DEFINING COMBAT READINESS}

The concept "combat readiness" is characterised by a proliferation of definitions. Schumm, Bell, Rice and Schuman (1996) state that the evidence for readiness is mixed because of different definitions for readiness being used in the major surveys. The first operational definition of combat readiness was given by Gal (1986) who defined combat readiness as a psychological attribute in terms of a soldier's choice or degree of commitment to, and persistence in effecting a certain course of action. His definition supports Lord Moran's statement (cited in Richardson, 1978) that it are not the number of soldiers but their will to win that decides battles. Gal (1986) states that the term "combat readiness" acts as an inadequate bridge between motivation and morale within the military context. MacDonough and Blankinship (cited in MacDonough, 1991) conceptualised the term "human readiness for combat" in terms of three variables, namely Individuals' Mental Readiness, Unit Readiness, and Actual Performance in Combat. Schumm, Bell, Rice and Schuman (1996) give a more comprehensive description when they define readiness as the level of preparedness for performing one's combat mission.

In refining the concept "combat readiness" the Ministry of Public Works and Government Services of Canada (1997) defines the concept as the state of preparedness of a unit to perform its assigned role. Lutz (1997), on the other hand, defines combat readiness as the measure of a force conducting operations successfully against a hostile force. Hooker (1998) states that generalship, leadership, operational and tactical planning and execution, logistics, intelligence and a host of other factors are critical for combat performance. Alternatively, Summers (1998) refers to combat readiness as a grocery list for war with quantifiable items that can be tallied, bought and paid for. However, he concludes that Vietnam has proved that such a shopkeeper approach to readiness is inadequate. Rosenberger (1999) holds a similar view to Summers (1998). The author emphasises that combat readiness in the US Army is measured by resources such as soldiers, leaders, equipment, ammunition and fuel. These resources, however, simply enable readiness and have always been an inadequate yardstick for readiness. Therefore he argues that the moral dimension should also be included. Hooker (1998) supports the abovementioned authors' critique of this way of measuring combat readiness: For many years Army personnel managers equated "personnel fill" with unit readiness.

Anonymous (undated, chapter 7) alludes to the multifaceted nature of combat readiness when he/she mentions two dimensions of concern in arriving at a definition of combat readiness: "Designed Combat Potential" and "Available Combat Potential". Designed Combat Potential is described as the pre-combat latent designed capacity of a force to achieve useful results in combat when organised, trained, equipped, supported, motivated, and led according to the force design against a design threat. Available Combat Potential is defined as the latent capacity of a force to achieve useful results in combat with its existing organisation, training, equipment, support, motivation and leadership. Vinson (2000) states that, for the US Army, readiness refers to a qualitative assessment of its ability to provide sufficiently trained and ready ground combat forces to execute all the requirements of the National Military Strategy successfully. The SANDF's Defence Inspectorate (van Vuuren, 2000, p.3) defines combat readiness as "...the state of readiness achieved by a military organisation, or part thereof which has been staffed, equipped, trained and sustained to successfully engage the enemy (to successfully accomplish the mission) in a disciplined manner and to inflict a crushing defeat on him...". Kruys (2001) comes to the simple conclusion that combat readiness means to be fully prepared and in a fit stafe to engage in battle or carry out military operations.

The US Department of Defence (undated) states that combat readiness is synonymous with operational readiness with respect to missions or functions performed in combat. Korb (1995), on the other hand, is of the opinion that readiness is not a synonym for military preparedness or capability. It is, rather, only one of four components of military capability, and it is not necessarily the most important. He says that a force can be ready, but not capable or vice versa. The SANDF's Defence Inspectorate (van Vuuren, 2000) emphasises that aspects such as military capability, operational readiness and combat readiness are closely interconnected and objectively depend upon one another. Although some authors (Hooker, 1998; Shamir, et al., 2000; McClure \& Broughton, 2000; van Vuuren, 2000) define the concepts combat readiness, unit readiness and operational readiness differently, commonalities between them are readily apparent. This view is supported by Kruys (2001), who states that the terms readiness, combat efficiency, combat proficiency and combat power are very often used to mean the same thing. Therefore, for the purpose of this study, these concepts will be treated as synonyms.

From the definitions above, two aspects of combat readiness can be identified. On the one hand there is a psychosocial dimension (psychological attributes) and on the other hand, a material dimension (e.g. the number of tanks and their serviceability, the availability of ammunition). Various authors emphasise the importance of the psychosocial dimension (the human factor) in battle and during deployments (Baynes, 1967; De Vries, 1993; Flora, 1992; Gal, 1986; Hooker, 1998; Shay, 2000; Taylor, 1991; Vinson, 2000). This view is expressed in the United States Department of the Army's Field Manual 100-1 (undated), which states that the readiness of a military force owes as much to the soldiers' state of mind as it does to his training and operational equipment. The process of looking at the material and training only is a mechanistic and structured process. Individual soldiers may have the best equipment and may receive the best training possible, but if they do not have confidence or trust in their abilities, equipment, personnel and training, their mission is 
most likely to fail. Therefore, it can be concluded that combat readiness is not only about equipment, training and capability, but more importantly, it is about the individual's and the group's state of mind. This state of mind includes their perception of their own combat readiness. In other words, combat readiness consists of two interdependent dimensions: the Psychosocial Dimension and Material Dimension. Gal (1986) confirms this interdependency when he concludes that motivational factors are interactive and not additive.

Combat readiness is therefore conceptualised in terms of an overlap between the psychosocial aspects (mental or human aspects) and the means at the disposal of the soldiers to conduct war (non-human aspects). The focus of this study is, however, being on the psychosocial aspects. The non-human indicator of combat readiness, such as the physical serviceability of military equipment, is not part of this study. Anonymous (undated, chapter 7) states that historical examples indicate that the behavioural component is more significant than the so-called structural component. This view is further emphasised by Anonymous (undated, chapter 8), who states that combat proceeds on the basis of perceptions of reality rather than reality itself. Misperceptions may result in what can be called "cognitive entropy of combat": the measure of uncertainty, confusion and disorder as perceived by the combatant. Therefore, it is important to measure the soldiers' perceptions of the various building blocks. The abovementioned cognitive entropy can be reduced by factors both internal and external to the combat arena. Thus, it can be postulated that a questionnaire which can measure combat readiness will be able to identify the areas in which cognitive entropy can occur. Hence the emphasis of this study is on the human being's perception of combat readiness. This may, however, include perceptions about aspects such as the serviceability of equipment, and medical support provided.

With the abovementioned as background, and given the above definitions of various authors (Anonymous, undated, chapter 7; Gal, 1986; Grange, 1999; Kruys, 2001; Lutz, 1998; Hooker, 1998; MacDonough \& Blankinship, cited in MacDonough, 1991; Ministry of Public Works and Government Services of Canada, 1997; Schumm, Bell, Rice and Schuman, 1996; Summers, 1998;
Vinson, 2000; van Vuuren, 2000), the following definition of combat readiness is proposed: the individual and/or collective state of mind of a soldier or a group of soldiers that will determine their performance during military operations. This state of mind is a function of the social trust and confidence these soldiers have, their worries and concerns, their familiarity with the enemy and the frontage, morale, and preconceptions of the opposing force. Confidence, social trust and morale are made up of various building blocks. Therefore, this state of mind is conceptualised as a multidimensional construct. This multidimensional construct is an important prerequisite for effectiveness and efficiency during deployment for peacesupport operations.

Based on the above discussion a proposed model of combat readiness is given in figure 1 . It is important to note that the shaded area is actually part of another dimension of combat readiness, which is known as "mission readiness". According to Lötter (personal communication, February 01, 2002) mission readiness can be defined as the readiness for a specific military operation, such as peace support in Burundi or a floodrelief operation in Mozambique. This particular study focuses specifically on generic readiness for peace-support operations in general. The shaded dimensions are thus not applicable to this study. A further breakdown of the independent variables can be seen in Figures 2 and 3.

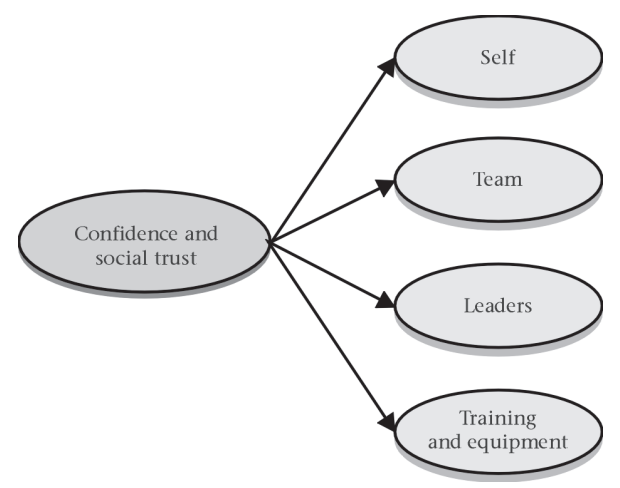

Figure 2: Confidence and social trust

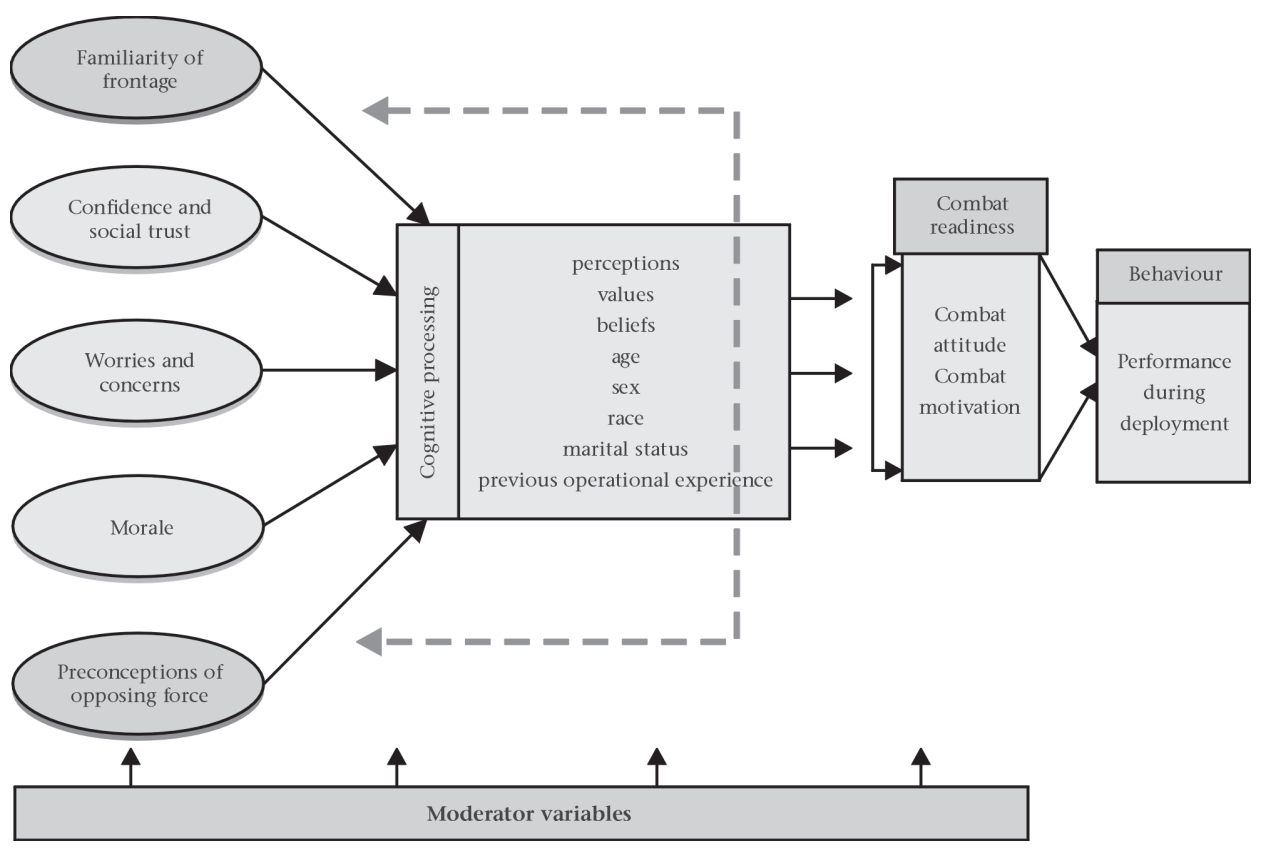

Figure 1: Psychosocial model of combat readiness

Note 1: Confidence in Self, Team, Leaders, Training and Equipment

Note 2: Cohesion, Esprit, General Willingness to Deploy, Discipline and Common Goal 


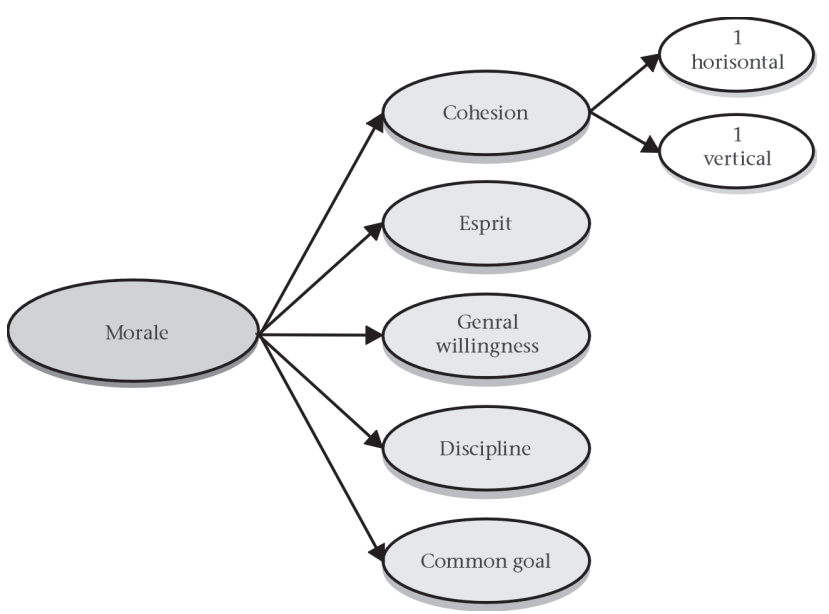

Figure 3: Morale
The dimensions relevant to combat readiness were clustered into three domains with eight sub-domains and two sub-subdomains. These domains are summarised in Table 1.

\section{MEASUREMENT INSTRUMENTS FOR COMBAT READINESS}

An overview of the combat readiness literature indicated that few studies have developed a measurement instrument of the concept with good psychometric properties. A notable study is that of Gal (1986) who explored the concept of morale within the military context. The author factor analysed data from a pre-war survey administered in May 1981 in the Israeli Defence Force. This questionnaire is known as the Combat Readiness Morale Questionnaire (CRMQ).

The factor analysis by Gal (1986) revealed eight factors: confidence in senior commanders; confidence in oneself, team

TABLE 1

DESCRIPTION OF THE VARIOUS DOMAINS OF COMBAT READINESS

\begin{tabular}{|c|c|c|c|c|}
\hline DOMAIN & $\begin{array}{l}\text { SUB- } \\
\text { DOMAIN }\end{array}$ & $\begin{array}{l}\text { SUB-SUB } \\
\text { DOMAIN }\end{array}$ & DEFINITION & AUTHORS \\
\hline \multirow[t]{4}{*}{$\begin{array}{l}\text { Confidence } \\
\text { and Social } \\
\text { Trust }\end{array}$} & $\begin{array}{l}\text { Confidence } \\
\text { in Self }\end{array}$ & & $\begin{array}{l}\text { The degree to which an individual believes in him- or } \\
\text { herself and his/her abilities to perform well during } \\
\text { military operations }\end{array}$ & $\begin{array}{l}\text { Department of the Army (Field Manual 22-102, undated), De Vries } \\
\text { (1993), Millgram (1991), Shay (2000) }\end{array}$ \\
\hline & $\begin{array}{l}\text { Confidence } \\
\text { in Team }\end{array}$ & & $\begin{array}{l}\text { The degree to which there is an emotional bond and } \\
\text { trust amongst soldiers }\end{array}$ & $\begin{array}{l}\text { Department of the Army (Field Manual 22-51), Department of the } \\
\text { Army (Field Manual 22-102), De Vries (1993), Kirkland, Bartone \& } \\
\text { Marlowe (1993), Kruys (2001), Malone \& McGee (1985), Manning } \\
\text { (1991) Ministry of Public Works and Government Canada (1997), } \\
\text { Murray (1980), Noy (1991), Richardson (1978) }\end{array}$ \\
\hline & $\begin{array}{l}\text { Confidence } \\
\text { in Leaders }\end{array}$ & & $\begin{array}{l}\text { The degree to which subordinates have confidence and } \\
\text { trust in their leaders }\end{array}$ & $\begin{array}{l}\text { Department of the Army (Field Manual 22-51), Elron, Shamir \& } \\
\text { Ben-Ari (1999), Finch (1998), Richardson (1978), Kirkland, Bartone } \\
\text { \& Marlowe (1993), Kruys (2001), MacDonough (1991), Ministry of } \\
\text { Public Works and Government Canada (1997), Noy (1991), Rush } \\
\text { (199), Hamir, Brainin, Zakay \& Popper (2000), Shay (1998, 2000), } \\
\text { Skaggs (1997), Spencer (1974) }\end{array}$ \\
\hline & $\begin{array}{l}\text { Confidence } \\
\text { in Training } \\
\text { and } \\
\text { Equipment }\end{array}$ & & $\begin{array}{l}\text { The degree to which soldiers believe that their } \\
\text { equipment and training can be relied on during } \\
\text { deployment }\end{array}$ & $\begin{array}{l}\text { Anon (undated, chapter 7, } 8 \& \text { 9), Baczkowski (undated), Brennan } \\
\text { ( 1998), Department of the Army (Field Manual 22-51), De Vries } \\
\text { (1993), Finch (1998), Grange (1999), Grau (1996), Kellett (1982), } \\
\text { Manning (1991), Kruys (2001), Rosenberger (1999), Shay (1998, } \\
\text { 2000), Spencer (1974), Taylor (1991), Vinson (2000), United States } \\
\text { General Accounting Office (1995), Zelenkov (2001) }\end{array}$ \\
\hline $\begin{array}{l}\text { Worries and } \\
\text { Concerns }\end{array}$ & & & $\begin{array}{l}\text { Those aspects that cause a person concern or worry } \\
\text { during deployment for military operations }\end{array}$ & $\begin{array}{l}\text { Anon (undated, Chapter 8), Baynes (1967), Chukunov (2000), } \\
\text { Department of the Army (Field Manual 22-51, undated), Elron, } \\
\text { Shamir \& Ben Ari (1999), Kruys (2001), Marlowe (2000), Richardson } \\
\text { (1978), Rush (1999), Spencer (1974) }\end{array}$ \\
\hline \multirow[t]{6}{*}{ Morale } & Cohesion & & $\begin{array}{l}\text { The lateral and vertical person-to-person bonding } \\
\text { within the primary groups of soldiers in a particular } \\
\text { unit }\end{array}$ & $\begin{array}{l}\text { Bartone \& Kirkland (1991), Department of the Army (Field Manual } \\
\text { 22-51), Department of the Army (Field Manual 22-102), Elron, } \\
\text { Shamir \& Ben-Ari (1999), Finch (1998), Flora (1992), Hooker (1998), } \\
\text { Ingraham \& Manning (1981, 1991), Kellett (1982), Kruys (2001), } \\
\text { Lutz (1998), McClure \& Broughton (2000), Ministry of Public Works } \\
\text { and Government Services Canada (1997), Richardson (1978), Shay } \\
\text { (2000), Skaggs (1997), Stewart (cited in Flora, 1992), Thomas \& } \\
\text { O'Hara (2000) }\end{array}$ \\
\hline & & $\begin{array}{l}\text { Horizontal } \\
\text { Cohesion }\end{array}$ & $\begin{array}{l}\text { The level of primary group (peer group) bonding } \\
\text { amongst soldiers at the same level in a military unit }\end{array}$ & $\begin{array}{l}\text { Anon (undated, chapter 7), Bartone \& Kirkland (1991), Department } \\
\text { of the Army (Field Manual 22-51), Riemer (1998), Rosen \& Martin } \\
\text { (1997), Shills \& Janowitz (cited in Riemer, 1998), Rush (1999), } \\
\text { Spencer (1974) }\end{array}$ \\
\hline & & $\begin{array}{l}\text { Vertical } \\
\text { Cohesion }\end{array}$ & $\begin{array}{l}\text { The level of leader-subordinate bonding in the military } \\
\text { chain of command }\end{array}$ & $\begin{array}{l}\text { Anon (undated, chapter } 7 \text { and 8), Department of the Army (Field } \\
\text { Manual 22-51), Rosen \& Martin (1997), Rush (1999), Shay (1998) }\end{array}$ \\
\hline & $\begin{array}{l}\text { Esprit } \\
\text { De corps }\end{array}$ & & $\begin{array}{l}\text { The bonding between soldiers and their secondary } \\
\text { groups (beyond primary group bonding). (Esprit de } \\
\text { corps relates the soldier to the institution of the unit) }\end{array}$ & $\begin{array}{l}\text { Department of the Army (Field Manual 22-51), Hooker (1998), } \\
\text { Ingraham and Manning (1981), Kellett (1982), Manning (1991), Noy } \\
\text { (1991), Richardson (1978), Taylor (1991) }\end{array}$ \\
\hline & $\begin{array}{l}\text { General } \\
\text { willingness } \\
\text { to deploy }\end{array}$ & & $\begin{array}{l}\text { The measure of a soldier's willingness or motivation to } \\
\text { participate in military operations }\end{array}$ & $\begin{array}{l}\text { Baynes (1967), Brown \& Moskos (1976), Manning (1991), Richardson } \\
\text { (1978) }\end{array}$ \\
\hline & Discipline & & $\begin{array}{l}\text { The degree to which soldiers comply with military } \\
\text { rules and regulations }\end{array}$ & $\begin{array}{l}\text { Anon (1995), Baynes (1967), Department of the Army (Field Manual } \\
\text { 22-51), Finch (1998), Kellett (1982), MacDonough (1991), Minister of } \\
\text { Public Works and Government Services Canada (1997), Richardson } \\
\text { (1978), Riemer (1998), Rush (1999), Shamir, Brainin, Zakay \& Popper } \\
\text { (2000), Shay (1998), Skaggs (1997), Thomas \& O'Hara (2000) }\end{array}$ \\
\hline
\end{tabular}


and weapons; unit cohesion and morale; familiarity with mission and frontage; confidence in immediate commanders; enemy evaluation; legitimacy of war; worries and concerns. Gal (1986) concluded that the data analysis suggests the existence of a higher order concept which he labelled "unit climate".

One of the positive aspects of this study is that the researcher made use of a method of factor analysis that prevents the creation of artefactors such as proposed by Schepers (1992). The study, however, had some limitations. The context did not include the possibility of peace-support operations; not all psychometric properties of the test are reported, such as the reliability of the items and scales; and the results cannot be generalised to a South African population.

The US Army Medical Research Unit-Europe (1999, May; 1999, November; 2000, June; 2001, January) studied soldiers during pre-deployment, mid-deployment, post-deployment and redeployment. They reported frequency statistics only. None of the psychometric properties of the questionnaire were reported. The following components were measured in the pre-deployment questionnaire: deployment attitudes, family issues (family concerns and family deployment), leadership (unit leadership, non-commissioned officer leadership and officer leadership), retention, military readiness (soldier pride, operational readiness, combat readiness), and peacekeeping attitudes. The questionnaire also made use of an anchored scale and did not make use of an intensity scale as proposed by Schepers (1992). Consequently the probability of acquiescence is increased.

A recent study conducted by Shamir et al. (2000) conceptualised perceived combat readiness as an important component of morale in terms of collective efficacy beliefs as they apply to military units. A principal component factor analysis was conducted and three factors were extracted which they named combat readiness (collective efficacy), unit discipline, and identification with the unit. This study, however, had some shortcomings. The researchers did not make use of a factor analysis procedure that makes provision for eliminating artefactors as proposed by Schepers (1992). They did not report the Eigen values of the end-reduced correlation matrix, and the item statistics for the various scales. The statistical power of the group-level analysis was limited. The study was conducted on the Israeli Defence Force which does not make the results generalisable to a South African population.

In view of the literature study on combat readiness it was decided to construct an instrument to measure combat readiness with acceptable psychometric properties. This instrument was based on the author's proposed model of combat readiness.

\section{PROBLEM STATEMENT}

Based on the abovementioned conceptualisation of combat readiness (see Figures 1 to 3 and Table 1), the main purpose of this study was to develop an instrument to measure combat readiness. The secondary purpose was to evaluate the use of this measuring instrument empirically. A corollary to this study was to determine the psychometrical properties of the empirically determined scales.

\section{METHOD}

\section{Sample}

Both the SANDF's Chief Director Corporate Communication and Chief Director Counter-intelligence gave permission for this study. The latter allocated a confidential security grading to the study. No results can be released without written consent from the Director Departmental Security. It was envisaged that 1000 respondents would be available, but owing to unforeseen factors 1500 of the SANDF's peace-support contingent were deployed in Burundi on short notice just prior to data collection. A non-probability random sampling procedure was used giving 461 respondents from units within the SANDF who would be most likely to deploy in a peace-support capacity. Eleven questionnaires were corrupted and could not be used. Therefore 450 questionnaires were suitable for data analysis.

TABLE 2

BIOGRAHICAL PROFILE OF RESPONDENTS $(\mathbf{N}=\mathbf{4 5 0})$

\begin{tabular}{lcc}
\hline 1. GENDER & FREQUENCY & PERCENTAGE \\
\hline Male & 425 & $94,4 \%$ \\
Female & 15 & $3,3 \%$ \\
No response & 10 & $2,2 \%$ \\
\hline TOTAL & 450 & $100 \%$ \\
\hline
\end{tabular}

2. AGE FREQUENCY PERCENTAGE

Younger than 24

$3,1 \%$

25-34

$70,2 \%$

$35-44$

313

$24 \%$

45 and older

$2,4 \%$

No response $0,9 \%$

TOTAL $100 \%$

\begin{tabular}{lcc}
\hline 3. HOME LANGUAGE & FREQUENCY & PERCENTAGE \\
\hline Afrikaans & 39 & $8,7 \%$ \\
English & 9 & $2 \%$ \\
Southern Sotho & 41 & $9,1 \%$ \\
Northern Sotho & 15 & $3,3 \%$ \\
Tswana & 21 & $4,7 \%$ \\
Swazi & 8 & $1,8 \%$ \\
Ndebele & 1 & $0,2 \%$ \\
Zulu & 63 & $14 \%$ \\
Xhosa & 233 & $51,8 \%$ \\
Shangana/Tsonga & 2 & $0,4 \%$ \\
Venda/Lemba & 5 & $1,1 \%$ \\
Other language & 2 & $0,4 \%$ \\
No response & 11 & $2,4 \%$ \\
\hline TOTAL & 450 & $100 \%$ \\
\hline
\end{tabular}

4. SPEAK ENGLISH FREQUENCY PERCENTAGE

\begin{tabular}{lcc}
\hline Never & 2 & $0,4 \%$ \\
Only at home & 7 & $1,6 \%$ \\
Only at work & 254 & $56,4 \%$ \\
Home and Work & 176 & $39,1 \%$ \\
No response & 11 & $2,4 \%$ \\
\hline TOTAL & 450 & $100 \%$ \\
\hline
\end{tabular}

5. POPULATION GROUP FREQUENCY PERCENTAGE

African

Asian

Coloured $86,7 \%$

White $0,7 \%$

No response $5,8 \%$ TOTAL $4,9 \%$

\begin{tabular}{lcc}
\hline TOTAL & 450 & $100 \%$ \\
\hline 6. HIGHEST QUALIFICATION & FREQUENCY & PERCENTAGE \\
\hline Grade 10 or lower & 98 & $21,8 \%$ \\
Grade 11 & 112 & $24,9 \%$ \\
Grade 12 & 172 & $38,2 \%$
\end{tabular}




\begin{tabular}{|c|c|c|}
\hline Grade 12 plus 1 year's study & 36 & $8 \%$ \\
\hline Grade 12 plus 2 year's study & 7 & $1,6 \%$ \\
\hline Grade 12 plus 3 year's study & 6 & $1,3 \%$ \\
\hline Grade 12 plus 4 year or more's study & 8 & $1,8 \%$ \\
\hline No response & 11 & $2,4 \%$ \\
\hline TOTAL & 450 & $100 \%$ \\
\hline 7. UNIFORM & FREQUENCY & PERCENTAGE \\
\hline Army & 432 & $96 \%$ \\
\hline Air Force & 2 & $0,4 \%$ \\
\hline Navy & 1 & $0,2 \%$ \\
\hline SAMHS & 5 & $1,1 \%$ \\
\hline No Response & 10 & $2,2 \%$ \\
\hline TOTAL & 450 & $100 \%$ \\
\hline 8. FIELD OF UTILIZATION & FREQUENCY & PERCENTAGE \\
\hline Logistics & 36 & $8 \%$ \\
\hline Personnel & 15 & $3,3 \%$ \\
\hline Finances & 1 & $0,2 \%$ \\
\hline Intelligence & 4 & $0,9 \%$ \\
\hline Infantry & 193 & $42,9 \%$ \\
\hline Signals & 14 & $3,1 \%$ \\
\hline Military Police & 4 & $0,9 \%$ \\
\hline Engineers & 151 & $33,6 \%$ \\
\hline Other & 23 & $5,1 \%$ \\
\hline No Response & 9 & $2 \%$ \\
\hline TOTAL & 450 & $100 \%$ \\
\hline 9. RANK & FREQUENCY & PERCENTAGE \\
\hline Col/Capt (SAN) & 3 & $0,7 \%$ \\
\hline $\mathrm{Maj} / \mathrm{Lt}$ Cdr to Lt Col/Cmdr & 3 & $0,7 \%$ \\
\hline CO/Mid to Capt/Lt SAN & 17 & $3,8 \%$ \\
\hline WO2 to WO1 & 4 & $0,9 \%$ \\
\hline Ssgt/Fsgt/CPO & 6 & $1,3 \%$ \\
\hline Sgt/PO & 26 & $5,8 \%$ \\
\hline Lcpl/AB to $\mathrm{Cpl} / \mathrm{LS}$ & 112 & $24,9 \%$ \\
\hline Pte/Amn/Sea & 268 & $59,6 \%$ \\
\hline Civilian-Ass Dir and higher & 1 & $0,2 \%$ \\
\hline Civilian-Lower than Ass Dir & 0 & $0 \%$ \\
\hline No Response & 10 & $2,2 \%$ \\
\hline 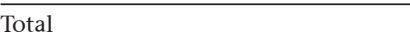 & 450 & $100 \%$ \\
\hline
\end{tabular}

questionnaire. However, some of these steps fell outside the scope of this study and were not followed in this case. This study is of an exploratory nature, it is thus not necessary to validate the instrument yet. Schepers's (1992) proposed criteria to overcome deficiencies such as acquiescence and differential skewness in test construction were used in the development of this instrument.

Five distinctive steps were followed during the construction of this questionnaire. Firstly, the term Combat Readiness was conceptualised, based on an overview of the relevant literature. Secondly, the domain of Combat Readiness was comprehensively defined within the particular context of peace-support operations. Thirdly, the sub-domain of Combat Readiness was identified from the literature and a study of existing questionnaires on combat readiness. The outcomes of these three steps were discussed in the above sections. Fourthly, certain behavioural indicators of the identified sub-domains were identified. This was done to operationalise the abstract construct of Combat Readiness (Swart, Roodt \& Schepers, 1999). These behavioural indicators were used to link the theoretical concept with empirical variables in accordance with the model of Feigl (1970) as indicated by Swart et al. (1999). This assisted in establishing high face and content validities. The theoretical model was also presented to experts in the field of peace-support operations and psychologists in the military to ensure face validity. Results from a focus group discussion held with members of the SANDF who returned from external deployment in a peacesupport capacity were used to validate the theoretical model qualitatively. Fifthly, care was taken in the construction of the item format in order to minimise the effect of acquiescence and differential skewness.

The objective of the questionnaire. The Peace-Support Operations Questionnaire (PSOQ) was constructed as a selfreporting questionnaire to determine the perceptions of respondents regarding the theoretical constructs of the various sub-domains of combat readiness. The PSOQ is a normative measuring instrument and can be utilised to examine interindividual differences between respondents.

Development of items. Based on the theoretically-based constructs, various sub-domains were identified that allowed for items to be formulated according to the hypothetical constructs. Care was taken to ensure that all the constructs could be measured, and would be well understood by members of the SANDF given their level of education and ability to speak English. The instrument was formulated in English only. The reason for this is that, according to the SANDF's language policy, English is the language medium in the SANDF. Items were formulated focusing on both the associated and disassociated perception of the soldiers. In order to retain the metric properties of the items, a seven-point scale was used (Schepers, 1992). The items were formulated to minimise prejudice and acquiescence. This format was also verified with a specialist in the field of test construction.

The respondents' biographical profile is given in table 2 . Most of the respondents were male (94\%) with the majority in the age group of 25 to $34(70,2 \%)$. More than half of the respondents' $(51,8 \%)$ home language was Xhosa. The respondents, however, indicated that $95,6 \%$ of them speak English either at work or at home, or both at home and at work. Approximately 86,7\% of the respondents were from the African population group. As far as qualifications are concerned, just more than half of the respondents $(50,9 \%)$ completed Grade 12 or higher. The majority of the participants were part of the Army (96\%). The majority of the respondents' field of utilisation was the Infantry $(42,9 \%)$ and the field of utilisation of $33,6 \%$ of them was Engineers. Most of the respondents came from the ranks $(59,6 \%)$ and $24,9 \%$ were in the group lance corporal to corporal.

\section{The Measuring Instrument}

Anastasi and Urbina (1997) and Smit (1981) suggest various steps for the development of a well-constructed and scientific

Three types of items were included in the PSOQ. The first type consisted of the items applicable to the associated component. For example, the question would be "How willing are you to give your whole-hearted cooperation to your officers?" The second type of items was applicable to the disassociated component. For example, "How willing are the members of your troop, platoon or company to give their whole-hearted cooperation to their officers?" The third type comprised generic items that were applicable to both the associated and disassoctiated components for example "How often does your Company Sergeant Major stand up (fight) for the rights of his/her troops?". The associated and generic parts can be combined to form a questionnaire applicable to the associated component. Otherwise, both the generic and disassociated components can be combined to form a collective questionnaire. 
A short pilot study was done on a group of soldiers in the technical field $(\mathrm{N}=53)$. The aim was to determine whether the questionnaire was clear enough, as well as determining whether participants experienced any language difficulties. Advice and information received at this stage were used to improve the questionnaire. It was specifically with the instructions of the Seven Point Continuous Scale that problems were experienced. The instructions were revised accordingly. After adaptations had been made, the original item pool of 50 was increased to 242 , and the instrument was applied to the sample.

\section{Data Collection Procedure}

The administration of the measuring instrument took place during an annual morale survey that was conducted by the SANDF's Centre for Effect Analysis situated the SANDF's Inspector General. The author administered the questionnaires personally. Respondents were informed of the purpose of the measuring instrument, their anonymity was guaranteed, and they were assured that the results would be published in a research report.

\section{RESULTS}

In view of the limited number of respondents the results from the sample were applied to the generic and associated part of the questionnaire only. This questionnaire consisted of 135 items. The variable to respondent ratio was acceptable (450 respondents:135 items). Tabachnick and Fidell (1996) indicated that, as a general rule of thumb, one should have at least 300 cases for factor analysis. The data was subjected to separate factor and item analysis according to a procedure developed by Schepers (1992), which prevents the forming of artefactors.

In order to determine the appropriateness of factor analysis, both the anti-image correlation matrix and the Bartlett test of sphericity was done during the first round of the firstorder factor analysis (Hair, Anderson, Tatham and Black, 1998; Tabachnick \& Fidell, 1996). Tabachnick and Fidell (ibid) emphasised that Bartlett's test of sphericity should only be done when there are fewer than five cases per variable, as was the case in this instance. After the first round, two items (Q68 and 074) were eliminated owing to low levels of antiimage correlation $(<0,50)$. The Kaiser-Meyer-Olkin measure of sampling adequacy was 0,938 (and Bartlett's test $<0,000$ ), implying that a factor analysis was meaningful. All calculations were done by means of the SPSS.
During the second round of the first-order factor analysis, the 133 items of the PSOQ were intercorrelated, and the matrix of intercorrelations was subjected to a principal factor analysis. Owing to space constraints the intercorrelation matrix (133 X 133) of the individual component is not given here. The unreduced intercorrelation matrix yielded 24 Eigen values greater than unity. Accordingly, 24 factors were extracted. These 24 factors were postulated on the basis of Kaiser's (1961) criterion and rotated to a simple structure through the Varimax rotation.

Subsequently, subtests were formed by summing all the scores of items with high loadings on a factor. Consequently 15 subtests were formed. Nine of the factors were eliminated because the item loadings were very low. Next, the 15 subtests were intercorrelated and the matrixes of the intercorrelations were subjected to a principal factor analysis. Subsequently, the unreduced intercorrelation matrix of the subtests yielded two Eigen values greater than unity. In this case two factors were extracted. The factor matrix obtained was rotated to a simple structure with the aid of a Direct Oblimin rotation. The matrix of intercorrelations $(15 \times 15)$ is given in Table 3 . The Eigen values are given in Table 4 and the rotated factor matrix is given in Table 5.

TABLE 4

EIGENVALUES OF THE UNREDUCED CORRELATION MATRIX OF THE SUBSCORES (15X15) AND TOTAL VARIANCE EXPLAINED

\begin{tabular}{lccc}
\hline SUBTEST & \multicolumn{3}{c}{ Initial Eigenvalues } \\
\cline { 2 - 4 } & Total & \% of variance & Cumulative \% \\
\hline 1 & 6,85 & 45,68 & 45,67 \\
2 & 1,26 & 8,42 & 54,10 \\
3 & 0,92 & 6,11 & 60,21 \\
4 & 0,88 & 5,86 & 66,07 \\
5 & 0,84 & 5,62 & 71,69 \\
6 & 0,76 & 5,08 & 76,77 \\
7 & 0,62 & 4,10 & 80,87 \\
8 & 0,56 & 3,70 & 84,58 \\
9 & 0,50 & 3,35 & 87,93 \\
10 & 0,44 & 2,96 & 90,88 \\
11 & 0,38 & 2,53 & 93,41 \\
12 & 0,32 & 2,14 & 95,55 \\
13 & 0,28 & 1,83 & 97,38 \\
14 & 0,26 & 1,76 & 99,15 \\
15 & 0,13 & 0,86 & 100,00 \\
\hline
\end{tabular}

TABLE 3

INTERCORRELATIONS MATRIX OF SUBTESTS TO THE PEACE SUPPORT OPERATIONS QUESTIONNAIRE

\begin{tabular}{|c|c|c|c|c|c|c|c|c|c|c|c|c|c|c|c|}
\hline & 1 & 2 & 3 & 4 & 5 & 6 & 7 & 8 & 9 & 10 & 11 & 12 & 13 & 14 & 15 \\
\hline SUBTEST 1 & 1,000 & & & & & & & & & & & & & & \\
\hline SUBTEST 2 & 0,829 & 1,000 & & & & & & & & & & & & & \\
\hline SUBTEST 3 & 0,606 & 0,740 & 1,000 & & & & & & & & & & & & \\
\hline SUBTEST 4 & 0,514 & 0,642 & 0,604 & 1,000 & & & & & & & & & & & \\
\hline SUBTEST 5 & 0,605 & 0,633 & 0,556 & 0,576 & 1,000 & & & & & & & & & & \\
\hline SUBTEST 6 & 0,086 & 0,118 & 0,116 & 0,126 & $-0,013$ & 1,000 & & & & & & & & & \\
\hline SUBTEST 7 & 0,698 & 0,749 & 0,689 & 0,598 & 0,561 & 0,145 & 1,000 & & & & & & & & \\
\hline SUBTEST 8 & 0,570 & 0,678 & 0,626 & 0,518 & 0,467 & 0,043 & 0,607 & 1,000 & & & & & & & \\
\hline SUBTEST 9 & 0,527 & 0,608 & 0,536 & 0,427 & 0,474 & 0,009 & 0,540 & 0,518 & 1,000 & & & & & & \\
\hline SUBTEST 10 & $-0,221$ & $-0,229$ & $-0,118$ & $-0,082$ & $-0,144$ & 0,112 & $-0,175$ & $-0,167$ & $-0,175$ & 1,000 & & & & & \\
\hline SUBTEST 11 & 0,714 & 0,725 & 0,647 & 0,537 & 0,558 & 0,090 & 0,695 & 0,515 & 0,534 & $-0,178$ & 1,000 & & & & \\
\hline SUBTEST 12 & 0,323 & 0,356 & 0,278 & 0,222 & 0,297 & $-0,067$ & 0,225 & 0,202 & 0,198 & $-0,150$ & 0,273 & 1,000 & & & \\
\hline SUBTEST 13 & 0,489 & 0,592 & 0,613 & 0,498 & 0,400 & 0,195 & 0,588 & 0,530 & 0,476 & $-0,085$ & 0,511 & 0,147 & 1,000 & & \\
\hline SUBTEST 14 & 0,357 & 0,343 & 0,229 & 0,226 & 0,300 & 0,056 & 0,263 & 0,272 & 0,267 & $-0,153$ & 0,329 & 0,190 & 0,214 & 1,000 & \\
\hline SUBTEST 15 & 0,317 & 0,387 & 0,301 & 0,366 & 0,287 & 0,018 & 0,335 & 0,301 & 0,303 & $-0,126$ & 0,393 & 0,213 & 0,366 & 0,164 & 1,000 \\
\hline
\end{tabular}


TABLE 5

ROTATED FACTOR MATRIX OF THE SUBTESTS OF THE PSOQ: DIRECT OBLIMIN ROTATION *

\begin{tabular}{lcc}
\hline & $\mathbf{1}$ & $\mathbf{2}$ \\
\hline SUBTEST 1 & 0,817 & $-0,148$ \\
SUBTEST 2 & 0,921 & $-0,048$ \\
SUBTEST 3 & 0,822 & 0,162 \\
SUBTEST 4 & 0,713 & 0,144 \\
SUBTEST 5 & 0,692 & $-0,130$ \\
SUBTEST 6 & 0,128 & 0,342 \\
SUBTEST 7 & 0,838 & 0,136 \\
SUBTEST 8 & 0,724 & 0,075 \\
SUBTEST 9 & 0,661 & $-0,020$ \\
SUBTEST 10 & $-0,204$ & 0,287 \\
SUBTEST 11 & 0,798 & $-0,031$ \\
SUBTEST 12 & 0,331 & $-0,278$ \\
SUBTEST 13 & 0,699 & 0,335 \\
SUBTEST 14 & 0,375 & $-0,139$ \\
SUBTEST 15 & 0,439 & $-0,010$ \\
\hline
\end{tabular}

*Rotation converged in 4 iterations

An inspection of Table 4 indicates that Factors 1 and 2 explain $54,1 \%$ of the variance. An analysis of Table 5 indicates that two separate factors were formed with respectively 120 and 9 items loading on each. The three items of subtest 10 were discarded because of a low loading on either Factor 1 or Factor $2(<0,3)$. Hence Factor 2 consists of the six items of Subtest 6 only.

In order to determine the extent to which the two factors intercorrelated with each other, the intercorrelation between the two factors was analysed, based on the results of the factor intercorrelation displayed in Table 6 . A correlation of $-0,075$ was found between the two factors which implies a common variance of $0,56 \%$ between the two factors, suggesting two distinctly separate factors. Next, two scales were formed by assigning all the items with high loadings on Factor 1 to Scale I and all the items with high loadings on Factor 2 to Scale II. These two scales were then subjected to two separate item analyses.

\section{TABLE 6}

\section{INTERCORREALTION OF ROTATED FACTORS}

\begin{tabular}{lcc}
\hline FACTOR & $\mathbf{1}$ & 2 \\
\hline $\mathbf{1}$ & 1,000 & \\
$\mathbf{2}$ & $-0,075$ & 1,000 \\
\hline
\end{tabular}

\section{Item Analysis}

The items of each scale were subjected to an item analysis to determine the reliability of each scale. An iterative item analysis was done with the National Institute for Personnel Research's NP 50 programme. Due to a lack of space the results of the item analysis on the contents of Scales I and II are not indicated but are available on request from the authors.

The item analysis of the 120 items of Scale I rejected item 9 after the first iteration and a reliability coefficient of 0,987 was obtained (according to Cronbach's coefficient alpha). The following subtests formed part of Scale I: Subtest 1-Leadership and Institutional Competency; Subtest 2-Team Relationships; Subtest 3-Military Affiliation; Subtest 4-Personal Commitment; Subtest 5-General Support; Subtest 7-General Readiness; Subtest 8-Skills and Abilities; Subtest 9-Social Intimacy; Subtest 11General Morale; Subtest 12-Threat from Disease; Subtest 13-Peer Relationships; Subtest 14-Confidence in Political Leaders; and Subtest 15-Off-duty Socialising. Collectively the contents of Scale I refer to the dimension of "Climate".
None of the six items of Scale II was discarded after the item analysis and a reliability coefficient of 0,791 was obtained (according to Cronbach's coefficient alpha). All these items were rotated prior to the first round of factor analysis. Jointly, the content of Scale II refers to the dimension of "Discipline".

The results of the item analysis on Scale I indicated that the reliability indexes $\left(\mathrm{r}_{\mathrm{gx}} \mathrm{s}_{\mathrm{g}}\right)$ of the items varied between 0,460 and 1,514 , and the item total correlation $\left(r_{\mathrm{gx}}\right)$ between 0,334 and 0,786 . For Scale II the reliability indexes $\left(\mathrm{r}_{\mathrm{gx}} \mathrm{s}_{\mathrm{g}}\right)$ of the items varied between 1,327 and 1,687, and the item total correlation $\left(r_{g x}\right)$ between 0,638 and 0,758 . The reliability indexes of both scales seem acceptable for further use $(>0,700)$.

\section{DISCUSSION}

The aim of this study was to explore the concept "combat readiness" through the conceptualisation and measurement of Combat Readiness within the South African military context with specific emphasis on peace-support operations. Combat readiness was defined as the individual and/or collective state of mind of a soldier or a group of soldiers, which will determine their performance during military operations. A psychosocial model of combat readiness was developed. Based on this model the Peace-Support Operations Questionnaire (PSOQ) was constructed, consisting of 242 items.

This questionnaire is made up of both associated disassociated components. In view of the limited number of respondents only the associated component of the questionnaire was included in this study. The associated component consists of 135 items on a seven-point self-rating scale, grouped into two subscales with an internal consistency of 0,987 and 0,791 (Cronbach's alpha) respectively. The favourable psychometric properties obtained for the PSOQ are particularly noteworthy, as other measures of combat readiness do not provide adequate supportive psychometric information (Gal, 1986; Shamir, et al, 2000; US Army Medical Research Unit-Europe, 1999, May, 1999, November, 2000, June, 2001, January). Also, the PSOQ was administered to a South African sample, suggesting that after refinement of the instrument it can be generalised to the South African population. Scale I measures the dimension of "Climate" and consists of the following 13 subtests: Leadership and Institutional Competency; Team Relationships; Military Affiliation; Personal Commitment; General Support; General Readiness, Skills and Abilities; General Morale; Social Intimacy; Threat from Disease; Peer Relationships; Confidence in Political Leaders; and Off-duty Socialising. Scale II measures the dimension of "Discipline" and consists of one subtest only. The two scales did not correlate highly with each other, which indicated two distinctively independent scales. The labelling of Scale I as Climate confirms the postulation of a higher order concept of Unit Climate by Gal (1986). Except for Discipline, all the other sub-domains are part of the overarching dimension of Climate. Discipline coincides with Shamir et al's (2000) extraction of a factor which they labelled Unit Discipline. It can be postulated that the combination of Climate and Discipline determines a military force's readiness for deployment for peace-support operations.

The results presented above confirm the multi-dimensionality of combat readiness. However, it shows that the factors postulated by a prior multi-dimensional theory of combat readiness (the psychosocial model of combat readiness) gives an unsatisfactory explanation of combat readiness and its sub-domains. Thus, the empirically derived factors and subdomains differ to some extent from the theoretically derived factors and sub-domains. This can, in part, be attributed to response naivety, which refers to the inability of respondents to discriminate empirically between what theorists see as a logical distinction between different concepts (Morrow, Eastman \& McElroy, 1991). 
Because of the exploratory nature of the study, a situational random sample was regarded as sufficient. Consequently, one of the limitations of this study is the small sample of units that was studied. The results of this study thus cannot be generalised to the whole of the SANDF because the majority of members included in this study came from the Army. The Navy, South African Military Health Services and the Air Force were under-represented. In future research the questionnaire should be applied to different populations in order to test its discriminant validity.

Despite this limitation, the valuable contribution of this research to the combat readiness literature cannot be underestimated. In addition to providing empirical support for some of the elements of combat readiness, the study indicated the possibility that military commanders tend to focus on the wrong elements when they evaluate combat readiness. This study pointed out important variables that impinge upon the behaviour of the soldier in anticipation of and during peace-support operations. The standardised questionnaire can be used by military commanders to identify focus areas guiding their preparation prior to deployment for peace-support operations. The questionnaire can also be used to study combat readiness in military operations other than peace support.

A host of new research possibilities present themselves for further investigation. Similar studies could be conducted to validate the results of this study in order to develop further an explicit theoretically and empirically derived multi-dimensional model of combat readiness. The research could be replicated by using the associated component only, on a more representative sample. Future research could also investigate whether there is a positive correlation between the score obtained on the PSOQ and actual performance during combat (as an external criterion).

The findings of this study suggest that there are certain other domains of combat readiness which commanders and behavioural scientists should consider when they want to develop interventions or combat readiness programmes for military units. To enhance the combat readiness of military forces prior to deployment, the findings of this study indicate that behavioural scientists in the military should focus on aspects such as: Leadership and Institutional Competency, Team Relationships, Military Affiliation; Personal Commitment, General Support, General Readiness, Skills and Abilities, Social Intimacy; Perceived Threat from Disease, Peer Relationships, Confidence in Political Leaders, and Off-duty Socialising.

\section{CONCLUSION}

Because of the limited scope of this study the use of the PSOQ to determine combat readiness may be regarded as simplistic. Therefore, it should be kept in mind that the psychosocial domain of combat readiness is only one part of the whole domain of combat readiness and that some of the other aspects, such as the serviceability of equipment, availability of fuel and ammunition, should also be taken into consideration in determining the combat readiness of a military force. Subsequently, further analysis of the combat readiness domain seems to be critical for optimal performance by the SANDF during peace-support operations. The refinement of a South African instrument to measure combat readiness is a priority and challenge for future research.

\section{ACKNOWLEDGEMENTS}

Appreciation is expressed to Prof J.M. Schepers, Prof Theo H. Veldsman, Col W. Urie, Dr P. Jordaan, Lt Col B. Vos, Major J. Hartzenberg and Mr J. Delport of UJ's STATCON for their insightful comments and assistance in the preparation of this manuscript, and to the members of the SANDF who voluntarily participated in this study.

\section{REFERENCES}

Anastasi, A. \& Urbina, S. (1997). Psychological testing. (7th ed.). New York: Prentice Hall.

Anon. (1995). The effect of peace operations on unit readiness. Retrieved June 07, 2001 from the World Wide Web: http://call.army.mil/products/spc_sdy/unitrdy/ execusum.htm

Anon. Chapter 7: Dynamics: The concept of combat power. Retrieved June 08, 2001 from the World Wide Web: http:// www.militaryconflict.org/chap7.htm

Anon. Chapter 8: Dynamics: Applications of combat power. Retrieved June 08, 2001 from the World Wide Web: http:// www.militaryconflict.org/chap8.htm

Anon. Chapter 9. Retrieved May 27, 2001 from the World Wide Web: http://www.rand.org/publications/MR/MR1018.11. index.html

Baynes, J. (1967). Morale: A study of men and courage. London: Cassell.

Batone, P.T. \& Kirkland, F.R. (1991). Optimal leadership in small army units. In R. Gal \& A.D. Mangelsdorff (Eds), Handbook of Military Psychology (pp.507-530). New York: John Wiley \& Sons.

Baczkowski, R.F. Tactical lessons for peacekeeping: US multinational force in Beirut 1982-1984. Retrieved June 02, 2001 from the World Wide Web: http://www.fas.org/man/dod-101/ops/ docs/baczkow.htm

Brennan, S.A. (1998) Train for domestic operations. War Peace and Security WWW Server. Retrieved June 08, 2001 from the World Wide Web: http://www.cfcsc.dnd.c/irc/nh/ nh9798/003.html

Brown, C.W. \& Moskos C.C. (1976). The American volunteer soldier: Will he fight? Military Review. Retrieved June 12, 2001 from the World Wide Web: http://160.149.101.23/ milrev/english/janfeb97/browncw.htm.

Chukunov, V.M. (2000). Military security consciousness and the mechanism of its moulding in the RF armed forces. Military Thought, 9(2): 67-74.

Department of the Army. A ready versatile army. Field Manual 100-1. Retrieved May 27, 2001 from the World Wide Web: http://www.adtdl.army.mil/cgi-bin/atdll/fm100-1/ch1. ht\#top

Department of the Army, Characteristics of combat-ready teams, Field Manual 22-102. Retrieved June 02, 2001 from the World Wide Web: http://www.uwosh.edu/departments/military_ science/class/fm22-102_ch1-4.htm

Department of the Army, Leaders manual for combat stress control, Field Manual 22-51. Retrieved June 01, 2001 from the World Wide Web: http://www.ptsdmanual.com/fm2251/fm2251.htm

Department of the Army (1986, May) Operations (FM 100-5). Washington. DC.

De Vries, R. (1993). The military tactical appreciation - sharpening the psychological combat edge. Armed Forces, March.

Elron, E., Shamir, B. \& Ben-Ari, E. (1999). Why don't they fight each other? Cultural diversity and operational unity in multinational forces. Armed Forces \& Society, 26(1): 73-98

Feigl, H. (1970). The orthodox view of theories: Remarks in defence as well as critique. In M. Radner \& S. Winokurs (Eds), Analysis of theories and methods of physics and psychology (pp.). Minneapolis: University of Minnesota Press.

Finch, R.C. (1998). Why the Russian military failed in Chechnya. Retrieved June 10, 2001 from the World Wide Web: http:// call.army.mil/products/spc sdy/98-16/russmil.htm

Flora, C.B. (1992). Book reviews. Armed Forces \& Society, 19(1):139160.

Gal, R. (1986). Unit morale: From a theoretical puzzle to an empirical illustration - An Israeli example. Journal of Applied Social Psychology, 16(6): 549-564.

Grange, D.L. (1999). Maintaining Readiness. Retrieved May 28, 2001 from the World Wide Web: http://www.cgsc.army.mil/ milrev/English/MarApr99/digest.htm. 
Grau, L.W. (1996). Russian minister of defense plans for a smaller, highly-trained, modern army within a decade. Foreign Military Studies Office, Retrieved June 02, 2001 from the World Wide Web: http://www.fas.org/nuke/guide/russia/ agency/modarmy.htm.

Hair J.F., Anderson, R.E., Tatham, R.L. \& Black, W.C. (1998) Multivariate Data Analysis (5th ed.). New Jersey: Prentice Hall.

Hooker, R.D. (1998). Building unbreakable units. Retrieved June 02, 2001 from the World Wide Web: http://www.usafa. af.mil/jscope/JSCOPE98/HOOK98.HTM.

Ingraham, L.H. \& Manning, F.J. (1981). Cohesion: Who needs it, what is it and how do we get it to them? Military Review, June: $2-12$.

Ingraham, L.H. \& Manning, F.J. (1980). Psychiatric battle casualties: The missing column in a war without replacements. Military Review, August: 18 - 29.

Kaiser, H.F. (1961). A note on Guttman's lower bound for the number of common factors. British Journal of Statistical Psychology, 14(1), 1.

Kellett, A. (1982). Combat motivation: The behaviour of soldiers in battle. Boston: Klawer-Nijhoff Publishing.

Kirkland, F.R., Bartone, R.T. \& Marlowe, D.H. (1993). Commander's priorities and psychological readiness. Armed Forces \& Society, 19(4): 579-598.

Korb, L.J. (1995). Our overstuffed armed forces. Foreign Affairs, 74(6): 22

Kruys, G.P.H. (2001). Combat readiness with specific reference to armies. In M. Hough \& L. du Plessis (Eds), Selected military issues with specific reference to the Republic of South Africa (pp.87-105). Pretoria: Institute for Strategic Studies.

Lutz, D.W. (1998). Unit cohesion and organizational change. Paper presented at the Joint Services Conference on Professional Ethics XX.

Lutz, R.R. (1997). Russian strategy in Chechnya: A case study in failure. A research report submitted to the faculty in partial fulfillment of the curriculum requirements: Air War College, Air University, Maxwell Air Force Base, Alabama.

MacDonough, T.S. (1991). Noncombat stress in soldiers: How it is manifested, how to measure it, and how to cope with it. In R. Gal \& A.D. Mangelsdorff (Eds), Handbook of Military Psychology (pp.507-530). New York: John Wiley \& Sons.

Malone, D.M. \& McGee, M.L. Jazz musicians and alonquin Indians, Military Review, 65(12): 57-59.

Manning, F.J. (1991). Morale. Cohesion and esprit de corps. In R. Gal \& A.D. Mangelsdorff (Eds), Handbook of Military Psychology (pp.507-530). New York: John Wiley \& Sons

Marlowe, D.H. (2000). Psychological and psychosocial consequences of combat deployment with special emphasis on the Gulf war. MR-1018/11-OSD.

McClure, P. \& Broughton, W. (2000). Measuring the cohesion of military communities. Armed Forces and Society, 26(3): 473-487.

Milgram, N.A. (1991). Personality factors in military psychology. In R. Gal \& A.D. Mangelsdorff (Eds), Handbook of Military Psychology (pp.507-530). New York: John Wiley \& Sons.

Ministry of Public Works and Government Services Canada. (1997). Suitability and cohesion. Report of the Somalia Commission of Inquiry Retrieved June 02, 2001 from the World Wide Web: http://www.dnd.ca/somalia/vol2/v2c19e. htm

Morrow, P.C., Eastman, K. \& McElroy, J.C. (1991) Concept redundancy and rater naivety in organizational research. Journal of Applied Social Psychology, 21, (3), 8-11.

Murray, W. (1980) Preparing for war: The German army during the phony war. Columbus: Ohio State University Press.

Newman, R.J. (1998). Can peacekeepers make war? Retrieved June 02, 2001 from the World Wide Web: http://www.usnews. com/usnews/issue/980119/19war.htm.

Noy, S. (1991). Combat stress reactions. In R. Gal \& A.D. Mangelsdorff (Eds), Handbook of Military Psychology (pp.507530). New York: John Wiley \& Sons.
Richardson, F.M. (1978). Fighting spirit: A study of psychological factors in war. London: Leo Cooper.

Riemer, J.W. (1998). Durkheim's "heroic suicide" in military combat. Armed Forces \& Society, 25(1): 103-120.

Rosen, L.N. \& Martin, L. (1997). Sexual harassment, cohesion, and combat readiness in US Army support units. Armed Forces \& Society, 24(2): 221-244.

Rosenberger, J.D. (1999). Reversing the downward spiral of combat readiness: Change the way we measure it. Retrieved June 01 2001 from the World Wide Web: http://www-cgs.army.mil/ milrev/English/NovDec99/rosen.htm

Rush, R.S. (1999). A different perspective: Cohesion, morale, and operational effectiveness in the German Army, fall 1944. Armed Forces and Society, 25(3): 477-508.

Sarkesian, S.A., Williams, J.A. \& Bryant, F.B. (1995). Soldiers, society, and national security. Boulder, CO: Lynne Rienner Publishers, Inc.

Schepers, J.M. (1992). Toetskonstruksie: Teorie en praktyk. Johannesburg: RAU-drukpers.

Schumm, W.R., Bell, D.B., Rice, R.E. \& Schuman, P.M. (1996) Marriage trends in the US Army. Psychological Reports, 78: 771-784.

Shamir, B., Brainin, E. Zakay, E. \& Popper, M. (2000). Perceived combat readiness as collective efficacy: individual- and group-level analysis. Military Psychology, 12(2): 105-119.

Shay, J.S. (1998). Cohesion, confidence and command climate: keys to preventing psychological and moral injury in the military service. Retrieved June 01, 2001 from the World Wide Web: http://www.usafa.af.mil/jscope/JSCOPE98/ SHAY98/HTM

Shay, J. (2000). Preventing psychological injury in military service. Boston: Department of Veteran Affairs Outpatient Clinic and Tufts Department of Psychiatry. Retrieved May 24, 2001 from the World Wide Web:

http://belisarius.com/umodern_business_strategy/shay/shay_ prevent_psy_injury.htm.

Skaggs, D.C. (1997). Creating small unit cohesion: Oliver Hazard Perry at the battle of Lake Erie. Armed Forces \& Society, 23(4): 635-668.

Smit, G.J. (1981). Psigometrika. Pretoria: HAUM.

South African Department of Defence (1996) South Africa's white paper on defence. Pretoria: South African Department of Defence.

Spencer, T.A. (1974). Psychology and the Soviet Soldier. Military Review, February:92-103.

Summers, H. (1998). Military and C4I. Retrieved June 11, 2001 from the World Wide Web: http://www.infowar.com/mil c4i/mil_c4i_050298c_j.shtml

Swart, C., Roodt, G. \& Schepers, J.M. (1999). Itemformaat, differensiële itemskeefheid en die faktorstruktuur van 'n selfvoltooiingsvraelys. Journal of Industrial Psychology, 25(1): 33-43.

Tabachnick, B.G. \& Fidell, L.S. (1996). Using multivariate statistics. (3rd ed.). New York: Harper Collins College Publishers.

Taylor, A.J.W. (1991). Individual and group behaviour in extreme situations and environments. In R. Gal \& A.D. Mangelsdorff (Eds), Handbook of Military Psychology (pp.491-505). New York: John Wiley \& Sons.

Thomas, T.L. \& O'Hara, C.P. (2000). Combat Stress in Chechnya: "The Equal Opportunity Disorder". Army Medical Department Journal, Retrieved June 09, 2001 from the World Wide Web: http://call.army.mil/fmso/fmsopubs/issues/ stress.htmm

United States Department of Defence. Combat Readiness. Retrieved June 09, 2001 from the World Wide Web: http://131.84.1.34/ doctrine/jel/doddict/data/c/01289.html.

United States General Accounting Office. (1995). Peace operations: Effect of training, equipment and other factors $o$ $n$ unit capability. Retrieved June 11, 2001 from the World Wide Web: http://www.fas.org/man/gao/nsiad-96-014. htm 
U.S. Army Medical Research Unit - Europe (1999, May) USAREUR Soldier Study I: Kosovo Pre-Deployment. U.S. Army Medical Research and Materiel Command, Walter Reed Army Institute of Research.

U.S. Army Medical Research Unit - Europe (1999, November) USAREUR Soldier Study II: Kosovo Mid-Deployment. U.S. Army Medical Research and Materiel Command, Walter Reed Army Institute of Research.

U.S. Army Medical Research Unit - Europe (2000, June) USAREUR Soldier Study III: Kosovo Post-Deployment. U.S. Army Medical Research and Materiel Command, Walter Reed Army Institute of Research.
U.S. Army Medical Research Unit - Europe (2001, January) Re-Deployment Psychological Screening of 1ID Soldiers Deployed to Kosovo. U.S. Army Medical Research and Materiel Command, Walter Reed Army Institute of Research.

Van Vuuren, L. (2000). Report by IG on readiness in the SANDF. Pretoria: South African Department of Defence.

Vinson, M.E. (2000). Structuring the army for full-spectrum readiness. Parameters, $\mathrm{xxx}(2): 19-32$.

Zelenkov, M. Y. (2000). Maintenance of morale in the military. (Russia). Military Thought. 09(6): 49.

Zelenkov, M. Y. (2001). Morale training and foreign armies. Military Thought. 10(1): 76.. 